LSE 'Europe in Question' Discussion Paper Series

\title{
The Social Question in a Transnational
}

\section{Context}

\author{
Alexander Somek
}




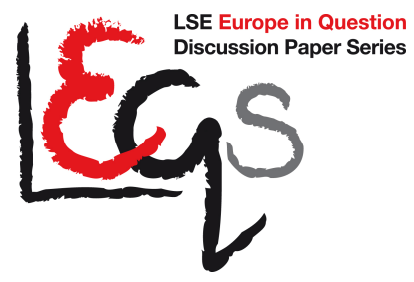

\section{Editorial Board}

Dr. Joan Costa-i-Font

Dr. Mareike Kleine

Dr. Jonathan White

Ms. Katjana Gattermann

All views expressed in this paper are those of the author and do not necessarily represent the views of the editors or the LSE.

(C) Alexander Somek 


\title{
The Social Question in a
}

\section{Transnational Context}

\author{
Alexander Somek ${ }^{*}$
}

\begin{abstract}
The social question has come down upon us in two different understandings. Modestly understood, it is about helping the needy and creating opportunities for disadvantaged members of society. More ambitiously conceived, by contrast, it is about extricating human life generally from the false necessities of market dealings. The article argues that the ambitious understanding is likely to become eclipsed in a transnational context. Such an eclipse, in turn, threatens to destabilize transnational arrangements as soon as some participants embrace broader ambitions.
\end{abstract}

* College of Law, University of Iowa

Department of Politics 428 Boyd Law Building

Iowa City, Iowa 52246-1113

Email: alexander-somek@uiowa.edu 
The Social Question in a Transnational Context

Egs 


\section{The Social Question in a}

\section{Transnational Context}

\section{The challenge}

In his well-known essay on global justice, Thomas Nagel set out to defend the view that the full requirements of socioeconomic justice are inapposite where political authority is not centralized. The circumstances of justice rather presuppose acts and relations bearing, directly or indirectly, the imprint of commonly authorised sovereign power. ${ }^{1}$ It is by virtue of the common authorisation of a coercive structure that the claims of justice become binding on members of a community. Where authorisation or sufficient centralisation are missing, the moral texture of relations devolves to a less demanding level. According to Nagel, this means, in particular, that "[m]ere economic interaction does not trigger the heightened standards of economic justice". ${ }^{2}$

In light of this contention, it is all the more remarkable that Nagel believes that poor societies ought to be able-on moral grounds-to benefit from the comparative advantage of lower labour costs. ${ }^{3}$ However thinly a moral minimum may be conceived of at the international level, Nagel believes that this precept ought to be included into the set. States defending their economy against imports from low-wage countries are therefore seen to be committing a moral wrong.

\footnotetext{
${ }^{1}$ See Thomas Nagel, 'The Problem of Global Justice' (2005) 33 Philosophy and Public Affairs 113147 at $120-121,123$.

2 Ibid. at 138.

3 Ibid. 143.
} 
If correct, Nagel's claim would be good news for the new Member States of the European Union. Since their share of transfer payments had been considerably lower for no other reason than their late, numerous and relatively poor admission to the club, ${ }^{4}$ the one chief redistributive mechanism working in their favour is wage competition. ${ }^{5}$ From Nagel's perspective, allowing this mechanism to work is a requirement of political morality. Even if the Union, owing to its lack of sovereign power, must not be held to the full scope of the principle of equal concern ${ }^{6}$-and hence may permit more inequality of distribution than national states-these inequalities must not originate from nations using their power in order to protect their people from interstate competition.

Such a bar on anti-competitive conduct may even be consistent with allowing greater economic inequality to arise within national societies. Obviously, the more fundamental moral minimum must trump any precept of national social justice. Hence, once the transnational context is taken into account, the demands of equality would be less exacting than they seem to be from a perspective that focuses on societies in isolation.

I do not want to dispute Nagel's views here. ${ }^{7}$ I mention them in order to underscore that even a philosopher who is quite sceptical of the demands of global justice supports a position that is commonplace among high-minded liberals of all persuasions. It is consistent with the intuition that those who

\footnotetext{
${ }^{4}$ See Giandomenico Majone, Europe as the Would-be World Power: The EU at Fifty (Cambridge: Cambridge University Press, 2009) at 55.

${ }^{5}$ See Perry Anderson, The New Old World (London: Verso, 2009) at 55.

${ }^{6}$ According to Nagel, ibid. at 127,130 , the full set includes rights of democratic participation, equal citizenship, non-discrimination, equality of opportunity, and the amelioration of unfairness of distribution.

${ }^{7}$ I add, in passing, that the view is supported by a variety of heterogeneous arguments. For example, according to the authorisation argument the demands of justice become applicable because as citizens of a sovereign state we are the co-authors of its laws. By contrast, the participation argument has it that "the engagement of the will that is essential to life inside a society" (ibid. 128) makes people responsible simply because they implicitly endorse the society they live in through their participation. There is a whole variety of additional arguments employed in this text, which I cannot discuss here.
} 
benefit relatively less than others from their labour have the right to benefit at the other's expense. It is as though low-wage workers incurred a sacrifice, however involuntary, which merits reward. Thus understood, protection from wage competition through the use of tariffs, quotas, or subsidies not only gives rise to an inefficient allocation of resources, it also constitutes a moral wrong. Mobilising national solidarity in order to prevent the poor from benefiting from the fruits of their own labour is mean. If jobs go to Mexico, Romania, or to the Ukraine, why bother? It is morally right.

\section{Outline}

Upon closer inspection, however, this moral intuition turns out to be less firm than it may appear. For example, it is not plausible why countries should be entitled to benefit from competitive advantages that are the result of widespread repression or exploitation. Allowing exploitative businesses to benefit from their wrongs would in fact subvert international solidarity. It even begs the question whether solidarity demands that organised labour in more affluent societies allow labourers located in other countries to benefit from low wages if these are also, and to a certain degree, the product of their own weakness. Would not strengthening labour across national bounds be the more attractive alternative? It seems, therefore, as though the moral intuition shared by both the liberal right and the liberal left is based upon the premise that competition rather than joint control across nations is the lex naturalis of labour conduct.

It should go without saying that not only is this far from being a self-evident truth; it is also potentially inimical to the interests of labour. 
It is with these doubts in mind that I would like to explore the meaning of the social question in a transnational context. In order to anchor the inquiry in what is potentially an ocean of perplexity, I would like to discuss transnational labour competition that has the potential to affect the larger fabric of co-operation among nations. The European Union is a fine battleground to study and used, in this article, for the purpose of illustration.

Evidently, talking of "the social question" signals interest in conflicts that reflect a clash of real historical forces, and not only some general human rights concerns, no matter how morally meritorious they may be. ${ }^{8}$ This explains why the article, following a very brief historical reminder, turns to Hannah Arendt's terribly puzzling claim that the social question is the nemesis of any project of political self-constitution. If she were right, societies haunted by this question would be condemned to lose their freedom, for they would be fatefully and fatally drawn into the maelstrom of necessity.

The article then turns to Friedrich August von Hayek's conjectures about how an international federation of states might provide an effective antidote to what he took to be the menace of redistribution. He believes that an international federation would exercise a disempowering effect on any more ambitious social policy. Intriguingly, the transnational context is not neutral vis-à-vis the social question. From Hayek's perspective, it promises to stamp it out.

What Hayek did not anticipate, however, is the disintegrating impact that existing social welfare states may have when they participate in such a federation. The effect has to do with the antithetical composition of the welfare state vis-à-vis the elementary precepts of a market society. Such a state is not merely a potential obstacle in the course of creating what Hayek

${ }^{8}$ See Thomas W. Pogge, World Poverty and Human Rights: Cosmopolitan Responsibilites and Reforms (Cambridge: Polity, 2003). 
called an international federation, but epitomizes the attempt to overcome the disempowering and alienating effect of market competition by political means.

The discussion of Hayek's views will be followed, therefore, by an attempt to reconstruct the point of the welfare state in a manner that does not reduce it to the role of the residual provider of much-needed handouts. Rather, such a state is a resolute attempt to extricate life from the depressing shackles of necessity. The liberal understanding, in which social policy is tied to the morally legitimate demands of less fortunate members of society, is thereby replaced with the larger ambition that Hayek hopes to see asphyxiated. The welfare state extended the significance of the social question from taking care of the needy and integrating unruly workers to something that is of concern to every member of society. The social question, thus understood, is about what society, qua collective body, can do for each in order to mitigate the risks and alienating effects that originate systematically from a market society.

What becomes of the social question when its more ambitious horizon is effectively eclipsed owing to the predominance of its modest counterpart? This question has recently arisen in the European Union. While the Commission and the ECJ pursue neoliberal projects aimed at reforming the institutions of capitalism in the Member States (for example, corporate law and industrial relations), ${ }^{9}$ the affected welfare states increasingly react with revulsion.

The effect that the Union has had on social policy has already been studied along several dimensions, ranging from reconstructing a problem-solving

\footnotetext{
9 See Martin Höpner and Armin Schäfer, 'A New Phase of European Integration: Organized
} Capitalism in Post-Ricardian Europe' (2007) 07/4 MPIfG Discussion Paper 15-17. 
gap $^{10}$ all the way down to identifying the legal-political structure that supports the implementation of an intellectually obsolete neo-liberal elite consensus. ${ }^{11}$

This article wishes to explore how the transnational context affects the meaning of the social question. When, in a transnational context, the merely modest ("taking care of the needy") or more ambitious ("extricating life from the market") understandings collide there is, evidently, no common understanding. Hence, it becomes increasingly unclear what the question is about. Consequently, it can regain its significance only if it is formulated in a reflexive manner, that is, with awareness that it needs to be re-articulated for a transnational context.

Intriguingly, in such a context, one can engage in reflection from two different perspectives on society. Matters of social policy can be addressed either from one perspective that presupposes political units or from another one that does not. The difference between these perspectives-one political, the other cosmopolitan-is due to spatial specifications of practical reason. Their relevance accounts for the different views on the conflict associated with cases such as Viking ${ }^{12}$ and Laval ${ }^{13}$. Since much ink has been spilled on these cases already, the article highlights three central to this type of conflict, namely, the distributive question in the relations between the workforces of two countries, the way in which Union law deals with struggle, and, finally, the collapse of the public-private distinction.

\footnotetext{
10 See the classical statements by Fritz W. Scharpf, 'The Joint-Decision Trap' (1988) 66 Public Administration 239-278; Governing Europe: Effective and Democratic? (Oxford: Oxford University Press, 1999) at 79.

${ }^{11}$ See, for example, Fritz W. Scharpf, 'The Double Asymmetry of European Integration, Or: Why the EU Cannot Be a Social Market Economy' (2009) 09/12 MPIfG Working Paper.

12 See Case C-438/05, International Transport Workers Federation, Finnish Seaman's Union v. Viking Line, [2007] ECR I-10779.

13 See Case C-341/05, Laval un Partneri Ltd v. Svenska Byggnadsarbetareförbudet, [2007] ECR I11767.
} 
In a reflexive form, the social question appears too divided against itself owing to warring cosmopolitan and political sensibilities, with the former likely to prevail over the latter. The predominance can be explained, in part, by the fact that the institutions in charge of managing a transnational context do not perceive it as a shared polity but rather as an administrative space, that is, a district for common problem-solving.

I conclude that a way out of the predicament on divided understandings can only be found by attending to the priority of justice over the maximisation of welfare.

\section{Arendt}

There is no canonical definition for the term "social question"; and yet, with some confidence it can be said that since the nineteenth century any reference to it has evoked the image of impoverished and miserable working masses and the challenge of raising them, without thereby risking upheaval, to the level of fully participating members of modern society. ${ }^{14}$ What fascinates, of course, is the use of the collective singular, for if the social question is of greater significance than an array of various smaller questions then it points to a function that society has to serve in order not to disintegrate.

Historically, the social question was not directly associated with constitutionalism, which was essentially a bourgeois project. Spectres of socialist revolutions aside, integrating the urban and rural working classes into political society apparently did not require overcoming certain constitutional basics. While it implicated major political choices, such as the introduction of general suffrage or a retreat from judicial activism, history

${ }^{14}$ See Tony Judt, Ill Fares the Land (London: Penguin, 2010) 174. 
suggests that liberal constitutionalism has been able to survive the requisite accommodations. They range from the rise of modern social security administration to the informal establishment of corporate political structures.

In light of such common wisdom it is all the more surprising that in her remarkable study On Revolution, Hannah Arendt perceived a profound conflict between one and the other. ${ }^{15}$ In the course of the French revolution, she claims, the attempt to stabilise a sphere of free civic action by constitutional means was undermined by how the social question asserted itself vis-à-vis the attempt to establish political freedom.

Evidently, for all that is doubtful about her analysis, ${ }^{16}$ Arendt's claim is based upon a deliberately narrow reading of the social question. ${ }^{17}$ According to Arendt, the social question is the political face of poverty. Poverty, in turn, is a profoundly anti-political force, for it gives rise to action in the form of its own negation. The poor cannot afford the luxury of choice. They are driven by their needs. Poverty, therefore, confronts humans with their dependence on the necessities of the life process. Even if man-made, poverty unleashes impulses that are beyond human control. When the political sphere is invaded by the dictate of needs, the constitution of free institutions is undone owing to the prevalence of irresistible urgency: ${ }^{18}$

[T]he social question [is] what we may better and more simply call the existence of poverty. Poverty is more than deprivation, it is a state of constant want and acute misery whose ignominy consists in its dehumanizing force; poverty is abject because it puts men under the absolute dictate of their bodies, that is, under the absolute dictate of necessity as all men know it from their most intimate experience outside all speculations. It was under the absolute dictate of necessity that the multitude rushed to the assistance of the French

${ }^{15}$ See Hannah Arendt, On Revolution (1963, reprint London: Penguin, 1990).

${ }^{16}$ For a perceptive critique, see Bruce Ackerman, We the People, vol. 1: Foundations (Cambridge, Mass.: Harvard University Press, 1991) at 206-212.

${ }^{17}$ Arendt, note 15 at 89, draws a fine line between the revolutionary pity that is felt for the lot of the poor and the universalisation underlying solidarity.

18 Ibid. at 60. 
Revolution, inspired it, drove it onward, and eventually sent it to its doom, for this was the multitude of the poor. When they appeared on the scene of politics, necessity appeared with them, and the result was that the power of the old regime became impotent and the new republic was stillborn; freedom had to be surrendered to necessity, to the urgency of the life process itself. [...] It was necessity, the urgent needs of the people, that unleashed the terror and sent the revolution to its doom.

This is the core of the argument. A momentous historical new beginning, which is the fruit of human action, becomes eclipsed and overwhelmed by biological necessity. ${ }^{19}$ Since the French revolution thus failed to mint into permanent constitutional form a new order of human choice, the social question turned out to be constitutionalism's nemesis. Political action is surrendered to historical forces whose overpowering movement is a manifestation of the necessity of the life process. The urgency with which needs assert themselves feeds into the tenacity with which the final goal of want satisfaction eventually authorises even resort to dictatorial means.

\section{Hayek}

One should not quibble over Arendt's claim before asking whether a free society might be able to vaccinate its constitutional system against contagion by necessity. Can there be a constitution that is impervious to destruction on social grounds?

Arendt's own conclusion was ambivalent and, basically, pessimistic. Political rule among equals presupposes the violent oppression of others who need to carry the burden of life for the rulers. Only modern technology, and not better political ideas, might be able to liberate mankind from this predicament. ${ }^{20}$ 
Arendt seemed to subscribe to what Daniel Bell quite perceptively calls the American substitute for socialism, namely, affluence. ${ }^{21}$ Poverty admits of only an economic, and not a political, solution..$^{22}$

Quite remarkably, a potential solution had already been presented before Arendt formulated the problem. In a 1939 article, ${ }^{23}$ Hayek insinuated that an international federal government of states is likely to rid itself of the social question, not owing to the gradual augmentation and expansion of benevolence, but by making the question structurally obsolete. A federal system that is international in its nature, Hayek conjectured, would put an end to government bailouts for ailing industries for the simple reason that there would not be enough popular support for aiding one region over another. The absence within such a system of what Mill would have called "common sympathies" 24 among compatriots would eliminate state intervention on mere political grounds. Moreover, under conditions of unequal economic development there is unlikely to be majority support for matters such as limiting working time or universal compulsory unemployment insurance. ${ }^{25}$ Hayek quite perceptively identified what would be described fifty years later by Scharpf as a "problem-solving gap". ${ }^{26}$ Even if the federation had jurisdiction, it would lack the majority necessary for its exercise. ${ }^{27}$ What is more, the states themselves are not in a position to sustain high social

\footnotetext{
${ }^{21}$ Quoted in Judt, note 14 at 184.

22 I doubt, however, whether Arendt was even interested in finding a "way out". For various good reasons, hers was a deeply pessimistic view of the modern world.

${ }^{23}$ See Friedrich August von Hayek, 'The Economic Conditions of Interstate Federalism' (1939) In Individualism and Economic Order (Chicago, University of Chicago Press, 1942) 255-272.

24 John Stuart Mill, Considerations on Representative Government (Buffalo: Prometheus Books 1991) at 308: "A portion of mankind may be said to constitute a nationality if they are united among themselves by common sympathies which do not exist between them and others-which make them co-operate with each other more willingly than with other people, desire to be under the same government, and desire that it should be government by themselves, or a portion of themselves, exclusively."

${ }^{25}$ See ibid. at 263.

${ }^{26}$ See Scharpf, note 10 at 79.

${ }^{27}$ See also Friedrich August von Hayek, The Road to Serfdom (London: Routledge, 1972) at 173.
} 
standards owing to the strictures of regulatory competition, ${ }^{28}$ at any rate so long as protectionism is held at bay through a strong regime of negative market integration. ${ }^{29}$

Any social policy that would go beyond taking care of the needy is likely to disappear in such a system. Hence, creating an international, rather than national, federal system is a core maxim of economic liberalism: ${ }^{30}$

The conclusion that, in a federation, certain economic powers, which are now generally wielded by the national states, could be exercised neither by the federation nor by the individual states, implies that there would have to be less government all round if federation is to be practicable. [...] [T] he abrogation of national sovereignties and the creation of an effective international order of law is a necessary complement and the logical consummation of the liberal program.

Not without prescience, Hayek noted that the pursuit of core liberal values becomes perfected beyond the nation state where national sympathies cancel one another out. ${ }^{31}$ An international federation reaps the benefits of statehood, namely a system of law enforcement, and erases solidarity:

That Englishmen or Frenchmen should intrust [sic] the safeguarding of their lives, liberty and property-in short, the functions of the liberal state-to a suprastate organisation is conceivable. But that they should be willing to give the government or a federation the power to regulate their economic life, to decide what they should produce and consume, seems neither possible nor desirable.

Hayek concedes that at the outset an interstate federation is likely to appear attractive only as a peace project. ${ }^{32}$ However, as soon as such a "suprastate"

\footnotetext{
28 See Hayek, note 23 at 268.

${ }^{29}$ On such "negative" powers, see ibid. at 267.

30 Ibid. at 266, 269.

${ }^{31}$ Hayek, note 23 at 265-266.

32 See ibid at 255 .
} 
system begins to involve economic union, ${ }^{33}$ its additional aim is not merely "prosperity" 34 but rather prosperity under conditions of economic liberalism. This means that the system will produce wealth unheeded of economic equality. ${ }^{35}$

\section{Disembedded peace and prosperity}

Since social policy is effectively disabled in such a system, inequality promises to be sustainable at the federal level as well as at the level of the states. Along with war, an international federation eliminates the social conflicts that are a major cause of war.

Remarkably, Hayek perceives an even deeper relation between maintaining peace and suppressing social conflict. In his view, national solidarity is a quite artificial arrangement. It gives rise to the paradoxical result that people identify with the interests of others even where their own interests may be entirely unaffected. This is irrational: ${ }^{36}$

There is no valid reason why any change which affects a particular industry in a certain territory should impinge more heavily upon all or most of the inhabitants of the territory than upon people elsewhere.

Why should a jeweller, for example, pay more taxes in order to bail out compatriot coal miners who are about to be laid off unless the baker's supply of coal would thereby be affected? Identification on the ground of nationality not only distorts the varying alignment of individual interests but also creates

\footnotetext{
33 The reason why it should is that without economic union the internal coherence of the federation would be threatened. See ibid. at 257.

${ }^{34}$ See J.H.H. Weiler, The Constitution of Europe (Cambridge: Cambridge University Press, 2009) at 244 , on prosperity as one of the values of the supranational project.

35 On liberalism as a political philosophy that is not concerned about economic inequality, see Steven Holmes, The Anatomy of Antiliberalism (Cambridge, Mass.: Harvard University Press, 1993) at 4.

36 Hayek, note 23 at 257.
} 
irrational antagonism between groups. Instead of fending rationally for their own interest across national bounds, people support irrationally what happen to be causes of insiders at the expense of outsiders: ${ }^{37}$

[...] [E]conomic frontiers create communities of interest on a regional basis and of a most intimate character: they bring it about that all conflicts of interests tend to become conflicts between the same groups of people, instead of conflicts between groups of constantly varying composition, and that there will in consequence be perpetual conflicts between the inhabitants of a state as such instead of between the various individuals finding themselves arrayed, sometimes with one group of people against another, and at other times on another issue with the second group against the first.

There is no tension between the pursuit of a peace project and the attainment of a liberal economic union. On the contrary, the goals are mutually reinforcing.

If Hayek is right, a transnational economic union is not one possible context among others in which one might pose the social question, as though this question might be dealt with at the level of families, clubs, nations, or the international community; rather, creating a space of transnational economic interaction is already a reply to the social question, namely, an effort put it to rest, at least in any form going beyond the charitable impulse underlying poor laws. Raising this question in such a context would be tantamount to invoking the Pope's authority in a Protestant congregation. Congregations of this type exist precisely to make appeals to the Pope irrelevant.

What Hayek believes an international federation to be able to accomplish is nothing short of what Arendt would describe as the taming of one necessity, the necessity of bodily urges, with the necessity inherent in how state conduct is dictated by the economic interest of constituencies. The cunning long-term 
result hoped for by Hayek is that members of these constituencies come to comprehend the irrationality of their national sympathies and find themselves thrown back upon their individual interest, which alone, in his opinion, is real. The international federation is a project of putting enlightenment into practice.

\section{Cosmopolitan administrative individualism}

Again, before one might rush quickly to dismiss Hayek's observations, it pays to examine their philosophical significance.

Under a transnational economic arrangement, people do not appear to see their social existence mediated by a place that they share with others and for which they jointly bear responsibility. Rather, it is political self-determination that is linked to such a place. Its focus rests on sustaining a common form of life, and this may require coming to the aid of those who are part of it. The normative and ontic priority of the common place over individual people is manifest in the significance attributed to being born into, or assimilating into, a society. Using a much belaboured analogy, the form of life can be likened to an orchestra whose sonoric signature is not affected by the occasional replacement of individual players over time. ${ }^{38}$ The orchestra comes first, the players grow into it.

By contrast, a transnational federal space is inhabited by citizens who could be at home, or not at home, anywhere in the world. They do not perceive their own life as being tied to a place or to a tradition of inhabiting a common space with others. The cosmopolitan citizens of economic liberalism may find that

38 Bruno Walter once observed that the sound of the Vienna Philharmonic Orchestra had not changed even after almost two generations. 
they have much in common with people who live in distant places and come to regard themselves, nonetheless, as members of the vegetarian community, the gay and lesbian community or the community of animal rights activists. Interestingly, they can conceive of themselves as members of these communities while living, in principle, in isolation. If they were asked what their political philosophy is they would likely reply that they are "individualists". Life does not present them with the challenge of finding their own niche in the social world that they already inhabit. Rather, their challenge is to pick and choose the location where they can be who they want to be no matter what the surrounding social world is like. If they were to form an orchestra, the sound would vary depending on the players. The life of cosmopolitan individualists is essentially gated. What matters to them is not the larger context of their doings but rather whether it is legal to do what they would like to do where they are.

The social question seems to have not much traction in this type of life. If it appears at all, then in the wide screen format of high-minded sentimental attention to global poverty. Addressing issues of this type is considered to be a matter of private charity.

One may still wonder what remains for political choice and action if the social question loses much of its significance. What comes to mind, no doubt, are the morally charged issues that capture the attention of people harbouring universalistic moral ideas. Such issues involve questions of freedom of expression, abortion, binge-drinking or gay marriage. They affect humanity as such. But in many constitutional democracies questions of this type have already become the province of constitutional courts. They are addressed only in their shadow and mediated by a conceptual world which is commonly identified as a realm of expertise. Indeed, in a transnational context, as the example of European fundamental rights protection shows, they become part 
of an international "conversation". ${ }^{39}$ As a result, there is nothing left to be determined by a free citizenry.

Ironically, the vision of human association that is consistent with economic liberalism is perfectly content with having the operation of free markets overseen by a wise administration of things. The regulatory void left by the very nearly obsolete social question is replaced with the administrative liberalism of risk-management and crisis-intervention. It ranges from economic fine-tuning and the repair of market-failure all the way down to "nudging" stupid people into doing the right thing on the basis of incentives or by channelling their conduct through irksome regulations. Of course, this administration would have to include some poor laws, the reason for which may either be charity or the long-term self-interest on the part of the propertied classes to anesthetise misery suffered by the lower ranks of society. The international federation, however, would prevent that social stabilisation and engineering through transfer payments (or, even better, paternalistic inkind donations of "good" things) could ever grow into a more ambitious format of social policy.

\section{The welfare state}

It must not be forgotten that economic liberalism has its own approach to poor relief, which is consistent, even if not co-extensive, with a very modest understanding of the social question. No rational liberal society would leave its marginalised members completely to their own devices. Rather, it would

${ }^{39}$ See Vicki Jackson, Constitutional Engagement in a Transnational Era (Oxford: Oxford University Press, 2010). 
use means-tested support in order to pacify the losers. ${ }^{40}$ Sustainable pacification may require, lest one produces a large and potentially unruly Lumpenproletariat, investing the underclass with sufficient resources to buy games, porn, and drugs. Once they have been engrossed by media and anaesthetised by pharmaceuticals it will not likely occur to them that they could rebel against their station. A degenerate underclass is, no doubt, the hallmark of a smart liberal society.

Nevertheless, Hayek sensed correctly that any social welfare state whose ambition is greater than preventing unrest endorses an antithesis to economic liberalism. This antithesis does not, in the case of a welfare state, amount to a rejection of markets. Rather, it is supposed to render their operations compatible with human existence.

Modern market societies expect everyone to be active and to be able to adapt to shifting opportunities. Agility and adaptability are indispensible where the calibration and satisfaction of needs is subject to the conditions of trade and barter. ${ }^{41}$ Both expectations, which arise from this system of needs, create a high risk of social exclusion for the inactive and inflexible, not least where inactivity and inflexibility are entirely involuntary. One can easily fall out of society at any time owing to ill health, accident, family stress, shifting demand in the labour market, loss of competitive edge, simple fatigue, existential boredom, old age, or other reasons of incapacitation. The counterfactual expectations of agility and adaptability can only be universalised under the condition that the bearing of the exclusion risk is universalised, too-not de facto, which may plausibly never be the case, but normatively. Everyone ought to be regarded as equally affected by an exclusion

\footnotetext{
${ }^{40}$ For accurate observations along these lines, see Abram de Swaan, "The receding prospects for transnational social policy' (1997) 26 Theory and Society 561-575 at 561-562.

${ }^{41}$ See G.W.F. Hegel, Elements of the Philosophy of Right (trans. H. B. Nisbet, Cambridge: Cambridge University Press, 1991) § 188, p. 226.
} 
risk that arises from the counterfactual expectation of infinite agility and adaptability. Nobody must claim an exemption, no matter how lucky he or she may have been. All who stand to gain from this type of society also equally stand to lose. One counterfactual premise ("all are at risk") is supposed to moderate the inaccuracy of the other ("all are agile and adaptable"). The resulting synthesis is the pooling of risk under some hypothetical veil of ignorance where no person is in the position to predict his or her place in society. On the ground of the normative supposition of equal vulnerability, the resulting insurance against risk can only be compulsory. ${ }^{42}$

Taken by itself, insurance would do no more than provide basic coverage against the mishaps of life. But a welfare state moves beyond this level inasmuch as risk-pooling reveals how the universal expectations of agility and adaptability is prone to dwarf human nature and potential. Agility ignores our capacity for contemplation, adaptability is a mockery of the freedom that would allow one to be a law unto oneself. Indeed, it is the irony inherent in the concept of modern civil society ("the system of needs") that at the moment that persons are emancipated from inequality of rank their dependence on the market nexus makes it difficult for them to be who they are. Instead of being able to actualise fully their human powers they have to reify their human nature into a human resource that has to acquire skills in order to serve as supply for shifting demand. The laws of supply and demand are indifferent to human biography and aspiration.

As is well known, Marx observed that the cause of the loss of control over one's own life and the accidental character of opportunities and pursuits is the profoundly disempowering effect of competition: ${ }^{43}$

\footnotetext{
42 See François Ewald, L'État-providence (Paris: Grasset, 1986).

${ }^{43}$ Karl Marx \& Friedrich Engels, Die Deutsche Ideologie, MEW vol 3. (Berlin: Dietz, 1978) at 76.
} 
Die Konkurrenz und der Kampf [der] Individuen untereinander er[zeugt und en]twickelt erst diese Zufälligkeit als solche. In der Vorstellung sind daher die Individuen unter der Bourgeoisieherrschaft freier als früher, weil ihnen ihre Lebensbedingungen zufällig sind; in der Wirklichkeit sind sie natürlich unfreier, weil mehr unter sachliche Gewalt subsumiert.

This accidental character is only engendered and developed by competition and the struggle of individuals among themselves. Thus, in imagination, individuals seem freer under the dominance of the bourgeoisie than before, because their conditions of life seem accidental; in reality, of course, they are less free, because they are more subjected to the violence of things. ${ }^{44}$

Coping with the exposure to risk necessitates alienation, and alienation cannot be overcome, according to Marx, unless people collectively exercise control over their fate. Individuals can live as a law unto themselves by overcoming the anarchy of capitalist production and distribution through acts of collective self-determination. ${ }^{45}$

As is well known, the social welfare state has always been supposed to be an alternative to both socialism and unbridled capitalism. It establishes common control not over production and distribution, but only over elementary risks of life. It stops short of realising a thick human community where individuals might be fully reconciled with their "species being" on the ground of the suspicion that attempts to create such a community would merely modify, but not mitigate, alienation and submission. Instead of aiming at full liberation it offers disentrapment or, put differently, decommodification. ${ }^{46}$ Instead of getting everyone, potentially, involved in the life of others, it promises individual liberation by alleviating the socially incarcerating effects

\footnotetext{
44 The source of the translation is

http://www.marxists.org/archive/marx/works/1845/german-ideology/ch01d.htm.

45 See Marx \& Engels, note 43 at 74.

46 See, generally, Gøsta Esping-Andersen, The Three Worlds of Welfare Capitalism (Princeton: Princeton University Press, 1990) 21-22.
} 
of adaption and dexterousness. Unemployment benefits, pension payments and health care signal that individual life is not a commodity that society can dispose of as soon as demand has abated.

The welfare state, nonetheless, is consistent with individualism and with shifting the focus of life towards the private sphere. This shift is always likely to undermine its authority since it gives rise to a plain and potentially derogatory service mentality on the part of its clients.

\section{The more ambitious social question}

Even though the welfare state is evidently fully compatible with liberal democracy, the social position that becomes universalised as the standard position of a member of society is no longer the property-owing citizen but the free labourer. The paradigmatic experience is not self-reliance, but selfalienation. The elementary social act is not freedom of choice but the reification of human nature into a resource. The most elementary threat does not originate from others pursuing their self-interest but rather from a structure of interaction in which one participates and from which one expects to benefit. Society is not perceived as the combined and somewhat haphazard result of an association of free individuals, but as the unwieldy product of man-made, and therefore false, necessity. Using Marxian-Aristotelian terminology, ${ }^{47}$ the social question that formulates an antithesis to liberalism addresses a necessity that is different from the urges dictating the lives of the poor. It is the self-made necessity revealed in a market-society's relentless appetite for agility and adaptability. 47 See Ekkehard Martens, '"Das Reich der Notwendigkeit" und "Das Reich der Freiheit". Ein
aristotelisches Lehrstück bei Marx' (1974) 28 Zeitschrift für philosophische Forschung 114-119. 
The partial decommodification of life-its disentrapment vis-à-vis the system of needs - is a common achievement. By virtue of being more than a mere fortunate effect of uncoordinated behaviour it presupposes boundaries. The universality of the problem posed by the system of needs requires particularistic solutions simply because they cannot emerge from horizontal dealings. If the number of beneficiaries could without anything further grow at any time, the reciprocity of commitments would be easily undermined. If the individuals whose contributions go into redistribution-the wealthy, the healthy, and the young - could easily opt out and make arrangements among themselves or immunise their wealth and capital from the grip of taxation, the answer to the social question would remain negative. It is an error to suppose that the particularity with which welfare states draw on "common sympathies" for their effectiveness is a deficient manner of addressing a universal problem. Rather, the particularity of bounded systems is justified inasmuch as it provides the key to dealing effectively with a universal problem. It inherits, dialectically, its universality from what it addresses. This means also that a resolution to the social question, ambitiously conceived, presupposes the state.

The change of meaning of the social question from relieving the lot of the poor to implementing an antithesis to economic liberalism-the shift from natural to man-made necessity - is not a matter of merely looking at things from a different angle. It is a historical sea change, which has had as its historical background the successful attempt to garner broader support from the middle class for social policy. ${ }^{48}$ It has given rise to a cluster of forms of life in Western European countries whose historical significance is not so easily erased. In the collective memory of European history it has been inscribed as a singular achievement, even though it may well be about to erode.

${ }^{48}$ See Judt, note 14 at 52-53. 
Two types of social question

\begin{tabular}{l|l|l} 
& modest & ambitious \\
\hline necessity & natural & man-made \\
\hline means & poor relief & social insurance \\
& and public \\
\hline aim & stabilization & emancipation \\
\hline
\end{tabular}

\section{The social question in reflexive form}

Typically, a transnational context gives rise to a situation where openly redistributive policies are rarely to be found at the federal level. In addition, in all likelihood there exist antagonisms between ambitious and modest constituent units, on the one hand, and between a modest federal level and some ambitious units, on the other.

At any rate, this has been the experience in the European Union. Aside from regional development programs (and the CAP, which is a different story), the pursuit of redistributive policies has not been not terribly significant. Social policy is largely concerned with co-ordinating efforts to integrate human resources into markets (employment policy, initiatives for "inclusion"). ${ }^{49}$ Owing to antagonism among the social systems of the Member States,

\footnotetext{
${ }^{49}$ See, for example, Diamond Ashiagbor, 'EMU and the Shift in the European Labour Law Agenda: From "Social Policy" to "Employment Policy"' (2001) 7 European Law Journal 311-330; Mary Daly, 'Whither Social Policy? An Account and Assessment of Developments in the Lisbon Social Inclusion Process' (2007) 37 Journal of Social Policy 1-19.
} 
agreements on matters such as wage policies, industrial relations or corporate taxes appear to be out of the question. ${ }^{50}$ Member States rather have every incentive to manipulate their own legal system in order to attract businesses and capital. The Commission and the Court, in turn, develop liberalisation strategies and raise the pressures of regulatory competition to the level of regulatory disarmament. ${ }^{51}$

These factors explain why a modest approach to social policy is not only characteristic of the federal level but also increasingly informing Member State policies, not least owing to the constraints established by the common currency and various instruments that have been adopted in order to come to the rescue of defaulting states. This inclination towards more modest approaches aside, it is nonetheless the case that a transnational context, in which full-blown welfare states participate, has a dual constitution. It is composed of political spaces and can be perceived, by actors harbouring "federalist" hopes, as moving towards becoming such a space in the future. At the same time, however, the transnational context recognises neither internal divisions nor common sympathies. There are only obstacles to individual ambition. It invites, therefore, social construction from a perspective that no longer links practices of common problem-solving to particular spaces or pre-existing loyalties.

A transnational federal system, therefore, is capable of providing the institutional underpinning for the actual relevance of two different spatial specifications of practical reason. One does not recognize boundaries and resembles in this respect economic structures. It is compatible with economic liberalism, but not necessarily biased in its favour. The other requires

50 See See Fritz W. Scharpf, 'The Joint Decision Trap: Lessons from German Federalism and European Integration' (1988) 88 Public Administration 239-278.

${ }^{51}$ See my 'Idealization, De-Politicization and Economic Due Process: System Transition in the European Union' in: B. Iancu (ed.), The Law/Politics Distinction in Contemporary Public Law Adjudication (Utrecht: Eleven International Publishing, 2009) 137-167. 
closure. $^{52}$ A transnational system, as has been anticipated by Hayek, is congruent with a type of practical reason that operates in an unbounded context and is, in this respect, decidedly cosmopolitan in its orientation. Simultaneously, however, it is not inadequate to approach social policy from a perspective that presupposes a bounded polity or even to project optimistically such a political perspective to the supranational level.

Both spatial specifications of practical reason-the cosmopolitan and the political-have their application in a transnational context. As a result, the reflection of the social question can take on either a cosmopolitan or a political form.

In the process of reflection, therefore, the distinction between the modest and the ambitious approach to the social question is transformed into a cosmopolitan and a political understanding, respectively. ${ }^{53}$ Nevertheless, as the discussion will show, a transnational context systematically favours cosmopolitan sensibilities.

\section{Cosmopolitan and political practical reason}

Cosmopolitan practical reason is not tied to the co-presence of others at a certain place. ${ }^{54}$ While cosmopolitan reasoning has to be mediated by certain beliefs about what it takes for humans to get along and, beyond that, to prosper, these beliefs are not formed in concrete exchanges with others but on

\footnotetext{
52 In order to clarify I should mention that it is indeed a risk of inclusion that is at stake here. Inclusion into a market society comes with the constant risk of exclusion. Inclusion is inextricably related to the risk of exclusion.

53 This is not the place to explain how these two spatial specifications of practical reason materialize in different forms of collective self-determination. See my forthcoming 'On Cosmopolitan Self-Determination' and 'Europe: political, not cosmopolitan".

54 For a clear statement, see Richard Vernon, Cosmopolitan Regard: Political Membership and Global Justice (Cambridge: Cambridge University Press, 2010) at 37.
} 
the basis of trust in expert knowledge and abstract moral principles. This knowledge treats human life and interaction as aggregate phenomena and is manifest in reliable accounts of the conditions under which it is possible for rational and sentient beings to lead successful lives. The knowledge that is relevant to cosmopolitan reasoning has as its object the facilitation of interaction and the management of various risks. It is universal in its orientation and relevant to places only inasmuch as such knowledge has to avail of a sphere of application. In this respect, it resembles software that can be run on any machine.

Cosmopolitan subjects are responsive to reasons that have them yield to reasonably trustworthy expertise feeding into regulations. Through insight into their own limited knowledge, the complexity of the world, the increasingly self-contained character of social spheres, their lack of time to deal with political questions, and their lack of access to political fora they can consider themselves better off when surrendering their judgement to administrative authority. They believe they have reason to trust the engineers of modern civilisation as long as they are given some choices between and among options at the end user level. The availability of choice in the private sphere reconciles cosmopolitan subjects with abstaining from choice in the public sphere. Political choice is not integral to cosmopolitan reason because allowing oneself to be guided by expert reason does not involve an element of identification with a community.

The other spatial specification of practical reason is political. It is linked to the co-presence of others within a certain space. What matters to it are encounters with those whose lives are not, then, represented through aggregate accounts of social fact. This includes the possibility that one will meet and be answerable to those individuals either in person or through their political representatives. The life of political beings does not take place just anywhere. 
The ultimate manifestation of practical reason is not universal moral concern, which may well inform its cosmopolitan counterpart, but rather political judgement, that is, the capability to assess the acceptability of common choices from the perspective of actual (and not only hypothetical) people and real groups that might be affected. Being reasonable presupposes the readiness to yield to the will of others with whom one shares a form of life. The reason for yielding is a commitment to the place. It encompasses respect for past projects, which have made the place into what it is, as well as concern about its future.

It bears emphasis that cosmopolitan and political practical rationality emerge vis-à-vis different institutional practices that account for their reasonableness. Given that political judgement has its ultimate focus on self-realisation within a form of life one shares with others, it presupposes a unit that is capable of affecting and acting upon a relatively autonomous totality. Not by accident, therefore, political practice is associated with the state. By contrast, cosmopolitan practical rationality does not presuppose a collective unit. It merely needs to finds an anchor in reliable knowledge that feeds into disembedded administrative-regulatory processes whose jurisdiction may even remain indeterminate across various levels. What matters is the rationality of the administrative process and not the authenticity of claims made by others.

The horizon of both forms of practical reasoning concerns the substance of social policy and thereby, indirectly, the meaning of the social question. Cosmopolitan social policy, by definition, cannot be concerned with maintaining relations and the integrity of a place. It will not materialise in large-scale urban development or planning projects. But it may very well be concerned with equality of opportunity. It is not, therefore, in and of itself complicit with the harsher forms of economic liberalism. Nevertheless, there 
are different ways of looking at problems depending on the form of selfdetermination involved.

In what follows, I would like to explore this dual constitution of social issues with an eye to what has become, prior to the Euro zone malaise, a most salient manifestation of the social question, namely, wage competition between workers from more and less affluent European countries. As is well known, such competition comes in two forms, namely through the provision of services by foreign workers in the host state (basically, the Laval situation) and through business relocation to a place with lower labour cost (of which Viking is a variation). The cases of Viking and Laval have given rise to a series of excellent commentaries in which the respective decisions were criticised mostly on methodological grounds. ${ }^{55}$ There is good reason to pay attention to these cases, for a certain type of conflict is represented in the substantive economic due process jurisprudence of the ECJ.

The conflict has more than one dimension. First, its legal articulation involves a collision between a fundamental freedom and a fundamental right. The ECJ, quite unsurprisingly, lends its support to the former. Second, underlying this legal articulation is the clash of interests of the workforces from different countries. Finally, this clash would not come about if capital were happy to employ labour wherever it finds it at the local cost. But since capital wishes to maximise returns by minimising costs, the conflict between members of the workforce is triggered by the mobility of businesses. This mobility, in turn, is a consequence of the struggle between capital and labour, from which, unless labour unites, capital is destined to emerge victorious.

\footnotetext{
55 For a particularly perceptive piece see Robert Rebhahn, 'Grundfreiheit vor Arbeitskampf - der Fall Viking' (2008) 3/08 ZESAR 57-65.
} 
I do not want to offer another detailed analysis of these cases. ${ }^{56}$ Rather, I would like to focus on three substantive themes that were struck by these cases. The first concerns the distributive question of which workforce is to benefit. The second is about the Court's attitude towards struggle. Finally, I would like to look at the impending cancellation of the distinction between public and private.

\section{The distributive question}

The last group of Member States joining the European Union entered with the confidence that access to the internal market would stimulate economic growth. Given that their productivity is usually relatively lower, they are able to compete with wealthier Member States as long as labour costs are lower, too. Of course, owing to demand for labour, wages are expected to rise in the long term. It is assumed that slowly but surely the economic conditions among the Member States are going to approximate. ${ }^{57}$

As is well known, nominal wage competition that reflects productivity differentials was deemed to be unobjectionable by the founders of the European Economic Community. Changes in the underlying equilibrium were expected to be counterbalanced by currency fluctuation. ${ }^{58}$ It was taken for granted, however, by the founders that wage competition had to be avoided. ${ }^{59}$ The reasons are obvious, not least because such competition affects mostly low-paid workers and benefits the rich. Wage competition would be to

\footnotetext{
${ }^{56}$ For a prior instalment, see the article cited in note 53.

57 This is the world-view of the so-called Ohlin report of the International Labour Organsation on the social effects of European economic integration. See Catherine Barnard, EC Employment Law (2d. ed., Oxford: Oxford University Press, 2000) 3-4.

58 See Florian Rödl, 'Transnationale Lohnkonkurrenz: ein neuer Eckpfeiler der "sozialen" Union?' In A. Fischer-Lescano et al (eds.), Europäische Gesellschaftsverfassung: Zur Konstitutionalisierung sozialer Demokratie in Europa (Baden-Baden: Nomos, 2009) 145-160 at 147.

${ }^{59}$ On the following, see ibid. at 147-148, 150-151.
} 
the detriment of very vulnerable members of society. It is difficult to see therefore, why the burdens of transnational integration ought to be carried by them.

Perceiving such an impact presupposes, however, a modicum of identification with the workers affected. The cosmopolitan outlook cannot take such identification for granted. What matters, rather, is a comparison of the situations of individuals. Since particularistic loyalties must not influence the weighing of interests and the interest of each must be given equal consideration, the reasoning is likely to take on a consequentialist form. Workers in the low wage economy are in a position to improve their situation even if it is at the expense of the workers from the high wage economy. But, arguably, this social cost can be legitimately discounted at least as long as the latter have a decent social safety cushion to fall back onto. Once the question of who would suffer more from unemployment is raised, it is obvious that workers from the low wage economy should be given the job. Their marginal utility gain outweighs the marginal utility loss of the others.

I think that the reasoning above rehearses an argument that would appeal even to the neoliberal left. Interestingly, however, the underlying consequentialism is quite limited. It focuses on the situation of workers alone. Evidently, however, the transfer of jobs does not involve a Pareto improvement since one party is worse off than before. The situation is also not Kaldor-Hicks efficient as long as merely the transfer between workers is taken into account. The low-standard workers, at any rate, would by definition not be so much better off that they could compensate the losers. There is a net loss on the part of the workforce, which is supposedly made up through transfer payments (coming from nowhere?). As long as the focus remains restricted to the redistributive transfer between workers it is clear that the high earning workers are expected to make a sacrifice from which not only low earning 
workers but others benefit as well, possibly even consumers. But consumers are an inhomogeneous group, and it is far from clear whether the laid off workers will enjoy the advantage of having to pay less for the goods that they used to produce. Most definitely, however, benefits will go to those receiving bonus payments at the end of a successful business year.

As a reason for sacrifice, one may want to invoke international solidarity. But it is a very strange form of international solidarity where one set of workers is supposed to support others without standing to gain in the future. International solidarity among workers is supposed to be to the benefit of all.

This perplexing expectation reveals a hidden focus on individuals as members of nations rather than individuals considered in isolation. If individuals mattered it would not at all be intuitively clear that the job has to be transferred to whoever is ready to earn less. What the consequentialist argument tacitly appeals to is overall national wealth. Workers are expected to incur a sacrifice simply because they are part of a more wealthy economy. This is a simple reversal of the nationalist logic. They are expected to suffer simply because their nation is relatively better off and it is not unlikely that they will suffer less than their competitors without jobs.

It is difficult to see why this argument should have moral appeal. It is tantamount to saying that the savings of Swiss, Norwegian or German blue collar workers may be legitimately used in order to fund developmental aid, which is a good cause, simply because they are members of a wealthy nation. They can easily do without their savings. Wouldn't one have to consider the distributive effects?

Consequently, I take it that even a sober economic analysis of the redistributive transfer of jobs needs to expand the focus and take into account the overall balance sheet. For Kaldor-Hicks efficiency to be obtained-which is 
not an appealing moral standard - the winners would have to be in a position to compensate the losers even when no actual compensation is forthcoming. Once the focus is expanded beyond workers, it becomes clear that many others would benefit from the transfer, notably managers, shareholders and consumers. Motors for luxury cars are no longer assembled in Germany but in Hungary. German workers are sent into unemployment and live off "Hartz 4" transfer payments, which are far from opulent. This is the cosmopolitan way. Of course, the benefits are difficult to calculate and largely speculative. But their existence may be easily conceded. Most remarkably, none of the beneficiaries are ever likely to meet the losers: not managers, not shareholders, and of course not people who can afford luxury cars.

The conflict between person-neutral cosmopolitan reason and person-relative political deliberation emerges clearly enough. Cosmopolitanism favours wage competition. It supports it not least because adverse effects are never seen. Cosmopolitan reason does not inhabit political space. People matter only hypothetically or in the form of aggregate numbers. From a political perspective, however, workers from a wealthier country are expected to incur a sacrifice because of their national situation. The consideration that may be given in support of such a sacrifice could only be the symbolic advantages of scale. The sacrifice is made for the sake of belonging to a "bigger" transnational regime. Glory and presence on a global scale overrides the realisation of distributive justice. Within a political space, a transfer that harms the worse off and benefits the better off would be appalling. It is willingly endured, however, by those who accord priority to taking pride in their country's flag. Such transfers, therefore, suggest a remarkable imperialistic logic of identification. 


\section{The cosmopolitan difference principle}

According to Rawls' classical account of distributive justice, inequalities of wealth and positions are acceptable if they are to the benefit of every member of society and in particular to the benefit of those who are least advantaged in a system that permits inequalities. ${ }^{60}$ This so-called "difference principle" has its sphere of application in bounded communities, more precisely, in societies understood as systems of co-operation which one enters at birth and leaves with death. Yet, claiming a primary role for domestic social justice in a cosmopolitan setting is likely be met with the objection that doing so is rearward, chauvinistic and ugly. To assume that under post-national conditions the nation state is the natural locale for the realisation of justice must appear naïve and out of touch with reality. What is more, there is no good moral reason to be more concerned about the folks at home than about people abroad. If the poor can be helped across borders, the distributive pattern that arises across nation states may be disturbing by domestic standards and give rise to greater inequality, but greater overall affluence may have to embrace this.

This is a remarkable rebuttal. If one were to formulate it as a principle of justice it would say that improvements in the position of the worse off, globally considered, are permissible even if those who were moderately better off before end up worse off afterwards and those who were already far better off benefit even more. Put differently, such a cosmopolitan difference principle accords priority to the lot of the globally worse and worst off even if improving their position increases inequality up to the point where it becomes excessive, that is, unwarranted by any standard such as the domestic difference principle. Such an excess might happen simply because there is no

${ }^{60}$ See John Rawls, $A$ Theory of Justice (Cambridge, Mass.: Harvard University Press, 1971) at 78. 
political mechanism at a transnational level that could dampen its impact. While the global poor benefit from the presence of markets, the wealthy benefit from the absence of the state.

It stands to reason, of course, whether such a cosmopolitan difference principle would be chosen in a hypothetical global original position ${ }^{61}$ over a system that establishes nation states in whom is invested the institutional wherewithal to realise a more egalitarian distribution. It should not escape our attention that the cosmopolitan difference principle presupposes a world order whose transnational basic structure embraces competition, but no taxes and transfers. Domestic political systems are embedded into this structure. They represent what Wolfgang Streeck famously called "market-embedded states". In a manner anticipated and desired by Hayek, constraints of competitiveness seriously obstructs any domestic attempt to moderate inequalities.

I have my doubts whether parties in a hypothetical original position would choose a system of market-embedded states over political self-control within limits. The only distributive mechanism considered relevant is the market. Already, in this respect, the cosmopolitan difference principle smacks of a rationalisation. Indeed, what is remarkable about it is that it represents a distributive justice argument which does not in the least encompass the strengthening of political rights or the establishment of structures of political participation. In a vein that is characteristic of economic liberalism, it is concerned exclusively with a transfer of income that does not involve state intervention. Effecting the transfer merely requires liberalisation, that is, a removal of obstacles.

${ }^{61}$ The "original position" is a device used by Rawls in order to deduce principles of justice. See ibid. at 17-22. 
The recurrent appeal to those who are even poorer or more disadvantaged than others bespeaks a remarkable reversal of Arendt's observations regarding the force of necessity unleashed by poverty. This is due to what one may want to call, modulating Phillips catchy phrase, ${ }^{62}$ "the politics of absence". The poor are not party to cosmopolitan conversation. They are only talked about. Since the poor are an inhomogeneous category and it is always possible, alas, to find a group whose lot is particularly heartrending along one or the other dimension, there are a large number of people who can be referred to as more deserving than others, in particular if those others are compatriots. Conceivably, the situation in Sub-Sahara Africa is worse than the situation in Moldova; at any rate, the contrast might be invoked in an argument about why aid efforts by the Union ought to be directed towards Africa rather than Moldova.

The result is voluntarism. Distributive justice becomes assimilated to charity when the poor are not present but merely referred to as potentially deserving receivers of aid and when there is no group to whom one owes special concern. What is more, when the poor or disadvantaged are invoked as objects of concern and there is no sovereign that could effectively tackle the problem, one arrives at a quite paradoxical utilitarianism that lacks power of action. In juxtaposition, cosmopolitanism and disempowerment come perilously close to producing objective hypocrisy. When there is always reason to bemoan someone more than others, there is always an easy excuse for remaining inactive.

This conclusion may appear polemical. But the antagonism between cosmopolitan and political reasoning about justice confronts us with the major philosophical question, which was addressed, however less concretely, by Nagel in the essay to which I referred at the outset. Assuming that the nation

62 See Anne Phillips, The Politics of Presence (Oxford: Oxford University Press, 1995). 
state, rather than a decentralised transnational economic system, is a setting in which it is possible to realise justice, the question arises whether the priority of justice, which has been held in high regard in liberal circles, is transitive in that it also accords priority to its locale of realisation. If so, the antagonism between cosmopolitan and political reasoning would have to be resolved in favour of the latter.

I conclude this highly tentative discussion with the proposition that there are no good reasons why workers in a transnational system should not have the right to stand up and defend their interests simply because they might possibly hurt the economic interests of other workers who are relatively worse off. In particular, there is no convincing distributive justice argument that would make their resistance unfair. It is not rational, in particular, to expect that the imperial splendour that accrues from participating in a transnational system is sufficient to outweigh an interest in employment.

\section{Struggle}

We have herewith already arrived at the next theme that is of central relevance to Viking and Laval, namely, struggle. I do not want to discuss the more general matter that a concept, which without anything further was once considered to be an elementary concept of sociology, ${ }^{63}$ has almost disappeared from our range of experience. Decades of immersion in the neoliberal view of the world have made us ignore struggle as an elementary type of action. There is rational conduct, there is competition, which is a subset of the former, and there may be combat, at least for a few desperados or unfortunate fellows who could not procure less risky jobs. It seems as

${ }^{63}$ See Max Weber, Economy and Society (trans. E. Fischoff et al., Berkeley: University of California Press, 1978) vol. 1, at 38 (where struggle (Kampf) is alas rendered as "conflict"). 
though what we recognise today is that human action falls either in the category of peaceful conduct or outright violence. But there is no recognition of struggle.

In Viking, even more pointedly than in Laval, trade union action is subjected to a strict test of proportionality. ${ }^{64}$ First, it asserted that actions taken in view of the conclusion of collective agreement are, when it comes to interferences with fundamental freedoms, legally tantamount to regulations of bodies whose business is to regulate employment. ${ }^{65}$ Whatever is done in anticipation of a contractual agreement is thereby treated as equivalent to acts of public power that are backed up with coercive sanctions. ${ }^{66}$ Second, the legitimate aim that may be pursued by trade union action in the Viking context was conceived narrowly. Action has to be tailored to protecting the interests of the unionised workforce currently in employ. ${ }^{67}$ Third, the pursuit of this aim is subject to strict scrutiny. ${ }^{68}$

Many of the problems raised by this case concern its holding. For example, the question whether a consumer boycott of a business that relocates to another country in order to save labour costs would be caught by freedom of establishment and fail on proportionality grounds. ${ }^{69}$ The answer is not quite

\footnotetext{
64 See Viking, note 12 paras. 75-90; Laval, note 13 paras. 101-111.

65 See Viking, note 12 paras, 36, 60, 65 .

${ }^{66}$ I leave aside, for the moment, the assimilation to the Commission v. France and Schmidberger situation which might also be construed as a situation where private persons interfered with public liberties. The Court played with this idea as well (see Viking, note 12 para 62 and also Laval, note 13 at para 84), however, it makes more sense to view them from the perspective of a duty to protect the exercise of a fundamental freedom. For a discussion of the resulting unclarity, see Rebhahn, note 55 at 62.

${ }^{67}$ See Viking, note 12 at paras. 77, 81. In Laval it was denied that the blockade action was capable of pursing a legitimate public interest case on the ground that the system of wage determination allegedly conflicted with the harmonisation brought about by the Posted Worker Directive. See Laval, note 13 para. 108.

68 See Viking, note 12 para. 84. In para. 88, the national court is encouraged to inquire whether the union would have had less restrictive means available and had exhausted all means before eventually taking action.

${ }^{69}$ Most intriguingly, this would also engage state liability for private conduct.
} 
clear. ${ }^{70}$ What I would like to point out, however, is that this jurisprudence rests on a profoundly unsympathetic attitude towards collective struggle.

The point of collective struggle is to compensate for the lack of public power without being able to create a full equivalent. Collective action by trade unions builds up private power for a certain moment. The economic clout of business is supposed to be matched with the power of human association. The clash is, put in slightly Habermasian terms, ${ }^{71}$ nothing short of an encounter between the systemic operation of money with a countervailing impulse which proves the capability of people to grow beyond themselves only if they succeed at acting together. Within the small universe of action, human control is re-established over systemic processes governed by business necessities. This power is, in principle, generated for the moment and, hence, precariously threatened with immediate decay. In contrast to public power, which is based upon a legal system, the power of collective labour struggle cannot be stored away by means of rules and regulations. It is not preserved and readily available in the form of permanent coercive bodies. Ideally, public power is always in place. The private power of human associations needs to be regenerated in every single instance and has to be surrounded by the imminence of something that will be even larger. ${ }^{72}$ Paradoxically, the generation of power only succeeds when it is brought about in anticipation of future events. The private power of association is threatening only when its reappearance is to be expected, that is, when contrary to its natural propensity it does not appear to be fleeting and transcient. The expectation of its future exercise can only be given credibility when its present exercise is drastic and excessive. Excessiveness is necessary to secure effectiveness over time.

\footnotetext{
70 See Rebhahn, note 55 at 62.

71 Siehe Jürgen Habermas, 'Hannah Arendts Begriff der Macht' in his Philosophisch-politische Profile (2d ed. Frankfurt aM: Suhrkamp, 1981) 228-248 at 245-247.

72 See George Sorel, Reflections on Violence (trans. T. E. Hulme \& J. Jennings, Cambridge: Cambridge University Press, 1999) at 62-63.
} 
For that reason alone, it is more than questionable to confront trade union action with the expectation to meet proportionality requirements. ${ }^{73}$ But even if one had to concede, for reasons that I cannot make out, that union struggle has to be subject to some proportionality test, it has to be noted that the ECJ applied this test in a manner that was particularly inimical to labour, for it restricted the legitimate aim of such acts. The flag of convenience policy combated by unions in the Viking case may, as had been revealed correctly by the proportionality test, in exceptional cases not protect the interest of concrete workers. ${ }^{74}$ The Court did not recognise, however, that the common pursuit of such action per se facilitates the development of solidarity among labour on a transnational scale. While struggle can create co-presence and thus pave the ground for political self-determination, proportionality isolates. Such an isolating perspective is consistent with cosmopolitan reasoning.

Finally, the application of the proportionality principle to exercises of fundamental rights by private persons as soon as their acts interfere with fundamental freedoms (such as free movement of goods, establishments or service) demotes individuals to agents of the public interest. Viking, ${ }^{75}$ as well as Laval, ${ }^{76}$ confirmed, even though on the usual shaky foundations, ${ }^{77}$ that the right to engage in collective action, including the right to strike, is recognised as a fundamental right of Union law. What the Court ended up doing in both cases, however, was to confront the exercise of this fundamental right with the interest protected by free movement and to submit the former to a public interest justification vis-à-vis the latter.

\footnotetext{
${ }^{73}$ It is also unusual by the standards of the legal orders of the Member States. In other words, it would be difficult to find a common constitutional tradition for that (unless one takes the Mangold style of reasoning as the governing standard). See Rebhahn, note 55 at 64-65.

${ }^{74}$ See Viking, note 12 at para. 89.

75 See Viking, note 12 at para. 44.

76 See Laval, note 13 at para. 91.

77 See Rebhahn, note 55 at 59-60.
} 
Establishing such a direction of justification is tantamount to a perversion of the interest protected by a fundamental right. In fact, the Court's way of thinking elevates fundamental freedoms to a level above fundamental rights. Guaranteeing fundamental rights is per se in the public interest. There is no need to justify their exercise. ${ }^{78}$ What requires justification is an interference with those rights. It would, indeed, be destructive of the very liberty protected by rights if their bearers had to come up with a public interest justification when availing themselves of their rights. Fundamental rights would no longer guarantee liberty, but rather individual opportunity to do one's bit in the pursuit of the common good. ${ }^{79}$ This reflects a pre-modern understanding of rights, which was actually overcome by the bourgeois revolutions. ${ }^{80}$

It may be objected that when the exercise of fundamental rights collides with a fundamental freedom, such as the right of establishment, one has to explore a public interest justification for the exercise of rights. Moreover, in cases where fundamental rights collide with one another there is no other way of resolving the collision than by adducing arguments in favour of each. Such arguments need to appeal to the public interest since only a public interest can justify interferences with rights.

But the objection characterizes the situation inaccurately. What is at stake in cases such as Viking and Laval is a matter that is only very inaccurately addressed by the court. The interference with a fundamental freedom (e.g., free movement of goods, persons, services etc.) arises because the Member State has committed itself in its own constitution to protect a fundamental right (e.g., freedom of speech, freedom of association or the right to strike). This is

\footnotetext{
${ }^{78}$ See Rödl, note 58 at 157-158.

${ }^{79}$ The point is trickier than it may seem, for any exercise of a fundamental right contributes to the public good of liberty created through the exercise of fundamental rights.

80 See Dieter Grimm, Recht und Staat der bürgerlichen Gesellschaft (Frankfurt aM: Suhrkamp, 1987).
} 
unfortunately rendered obscure by the Court's heedless absorption of the Member States' role as protectors of rights by claiming that Union law also recognises these rights. Correctly understood, therefore, what is at stake is that the state allows an interference with a fundamental freedom because it is under a constitutional obligation to guarantee a fundamental right. When the matter is seen from this perspective, the public interest that can be invoked to justify restrictions on a fundamental freedom (or even a fundamental right) cannot be found in the reasons that the right holders themselves might have to avail themselves of such a liberty. The public interest of the state pertains, indeed, to respecting the liberty of men and women to avail themselves of the right for the pursuit of their own private interest. The interest of public power is to protect private liberty as such and not the specific reasons that may have motivated the exercise of a liberty. This public interest is of a second-order and hence not co-extensive with the sum total of all interests with which private persons exercise their rights. It would be tantamount to denying these persons their liberty if one expected them to present a public interest justification whenever their conduct interferes with the rights or freedoms of others. In a situation where potential exercises of fundamental freedoms (e.g., registration of a vessel) are thwarted by exercises of fundamental rights (e.g., strikes or blockades), all that has to be demonstrated is that a legal exercise of a fundamental right is at stake and not how that exercise is not out of proportion vis-à-vis fundamental freedoms. The fact that it is incumbent on states to respect fundamental rights is Perseus' shield saving the fundamental right from having to face the Gorgon of the fundamental freedom directly.

What the Court should have examined, therefore, is the question in the abstract, namely that this is a situation that engages a state's responsibility to protect fundamental rights. This would have permitted, even if not necessitated, an extension of the principle developed in Albany to this type of 
case. The Court could have concluded that trade union action, as long as it stays within constitutionally determined bounds, unavoidably has marketdistorting effects and hence needs to be exempted from the reach of free movement provisions. The Court explicitly rejected this conclusion on the false premise that it is not inherent in the exercise of trade union rights to "prejudice" fundamental freedoms to a certain degree. ${ }^{81}$ This premise is false because almost any action by unions is likely to impede intra community commerce, if even only indirectly. ${ }^{82}$

Stating the question in the abstract would have also re-established the ordinary burden of justification. The question would have been, then, whether the protection of a fundamental freedom is strong enough to justify interferences with the states' obligation to keep its promise to its citizens to protect their fundamental rights. By reversing this direction of justification the Court, in fact, consolidated fundamental freedoms to the fundamental right to engage freely in any transnational economic activity. This is the essence of substantive economic due process. ${ }^{83}$

I take from this discussion that we seem to have already forgotten that the original homestead of the proportionality principle has been the administrative office. ${ }^{84}$ Already its transposition to legislation must appear doubtful. In a memorable article, Hans Linde pointed out that even the application of a simple rationality test fails to capture the logic of negotiations underlying political processes. It confronts legislation with a false and alien expectation of rationality. ${ }^{85}$ This is, of course, all the more true for trade union

\footnotetext{
${ }^{81}$ See Viking, note 12 at 52.

${ }^{82}$ See Rebhahn, note 55 at 65 . The question is, of course, whether the Keck doctrine would have to be applied to cases that simply affect the volume of trade.

${ }^{83}$ For a further analysis of this point, see the article cited in note 56.

${ }^{84}$ For a most recent reminder, see Moshe Cohen-Eliya \& Iddo Porat, 'American balancing and German proportionality: The historical origins' (2010) 8 International Journal of Constitutional Law 263-286 at 271.

85 See Hand Linde, 'Due Process of Lawmaking' (1975) 50 Nebraska Law Review 195-255.
} 
action. The proportionality principle has its home in the administrative context. Not by accident is it a standard of public reasonableness that fits any non-political context. It is perfectly amenable to cosmopolitan practical reason.

By contrast, political practical reason is often enmeshed in struggle, for it is exercised not merely on the basis of hypothetical considerations of needy people, but under conditions marked by the co-presence of people raising claims. Politics is also not exclusively the realm of deliberation and procedures. It is not fully compatible with, even though it is increasingly absorbed by, the calm and cool world of administrative procedures, where any loud assertion of positions is considered to be out of place. Political action is profoundly misunderstood when a court isolates the self-interested perspective of workers who want to preserve their job. Collective struggle is the school of universalization, with the power to establish ties of transnational solidarity.

What Viking reveals, rather, is that widespread collective disempowerment is already taken for granted. It is understood that folks merely want to protect their own interests. Once more, the cosmopolitan view turns out to be incompatible with the political perspective.

\section{The demise of the private sphere}

With the above remarks I already touched upon the third question, namely, the disappearing of the distinction between public and private agents in the common market. Anyone's acts may, under certain conditions, be capable of constituting an interference with fundamental freedoms and therefore be just as repugnant as an illicit interference by the state. In Viking, one encounters 
this demise in two different ways, one of which is narrow while the other is broad. Both are stated in one paragraph of the Viking opinion with the purport that what is formulated is one and the same idea ${ }^{86}$ But it is not.

According to the narrow formulation, non-state action, such as the blockade of a production site, comes within the purview of the horizontal effect of a fundamental freedom (other than free movement of workers) when the action is "inextricably linked to" or "aimed at" the conclusion of a collective agreement. ${ }^{87}$ This formulation is novel. It does not actually base horizontal effect on the idea of securing equal treatment in a supranational context of application. ${ }^{88}$

The broad formulation takes its cue from case law affecting free movement of goods, which deals mostly with how demonstrations interfered with that right. ${ }^{89}$ In retrospect, the cases are presented as though they had introduced the principle of horizontal effect. ${ }^{90}$ This is yet another instance of the Court's practice of creatively misreading its own jurisprudence, for the prior case law obviously affects the state's failure to protect the free flow of commercial traffic in Europe. ${ }^{91}$ Even though the difference between the state's duty to

86. See Viking, note 12 para. 65.

87. See Viking, note 12 paras. $36,60$.

88. See Case C-36/74, Walrave and Koch [1974] ECR 1405.

89. See Case C-265/95, Commission v. France [1997] ECR I-6959 para. 30; Case C-112/00, Eugen Schmidberger, Internationale Transporte und Planzüge v Republik Österreich [2003] ECR I-5659 at para. 57 and 62. Both decisions are mentioned in Viking, note 12 at para. 62.

90. See Viking, note 12 at para. 62 .

91. Here is what the Court concluded in Commission v. France, note 91 at para 66: "[I]t must be held that, by failing to adopt all necessary and proportionate measures in order to prevent the free movement of fruit and vegetables from being obstructed by actions by private individuals, the French Government has failed to fulfil its obligations under Article 30, in conjunction with Article 5, of the Treaty and under the common organizations of the markets in agricultural products". And here is what the Court said in Schmidberger, note 91 at paras. 59-60: "Consequently, Articles 30 and 34 of the Treaty require the Member States not merely themselves to refrain from adopting measures or engaging in conduct liable to constitute an obstacle to trade but also, when read with Article 5 of the Treaty, to take all necessary and appropriate measures to ensure that fundamental freedom is respected on their territory (Commission v France, cited above, paragraph 32). Article 5 of the Treaty requires the Member States to take all appropriate measures, whether general or particular, to ensure fulfilment of the obligations arising out of the Treaty and to refrain from any measures which could jeopardise the attainment of the objectives of that Treaty. [...] Having regard to the fundamental role assigned to 
protect and horizontal effect may be imperceptibly thin in certain instances, ${ }^{92}$ it is quite clear in both practice and principle. It affects the remedy. ${ }^{33}$ Whereas horizontal effect would give rise to a remedy against another private party in an ordinary court of law-a tort claim, for example-a violation by the Member State of its obligation to protect a fundamental freedom pursuant to Article 5 of the EC Treaty against interference by private parties would give rise to a claim against the state. The remedy may indeed again be a tort claim against the state that is based on the state's failure to comply with Union law..$^{94}$

According to the broad formulation, which thus expands the focus on private acts more generally, the activity in question may be causally even farther removed from a collective agreement. The theory that might underlie this type of conclusion was clearly expressed by AG Maduro in his opinion where he elaborated on the horizontal effect of free movement positions. ${ }^{95}$ In a manner reminiscent of nineteenth century Begriffsjurisprudenz (conceptual jurisprudence), he uses disparate case law concerning the free movement of workers and occasional cases concerning the free movement of goods in order to extract the following general principle (at para. 43):

the free movement of goods in the Community system, in particular for the proper functioning of the internal market, that obligation upon each Member State to ensure the free movement of products in its territory by taking the measures necessary and appropriate for the purposes of preventing any restriction due to the acts of individuals applies without the need to distinguish between cases where such acts affect the flow of imports or exports and those affecting merely the transit of goods." From the reference to Article 5 of the EC Treaty and the language of the opinions is emerges clearly that the Court was concerned with the obligation of Member States and not with horizontal effect.

92. See Mattias Kumm, 'Who Is Afraid of the Total Constitution?' (2006) 7 German Law Journal 341-369 at 360-362.

93. The matter is completely conflated in the AG Maduro's opinion, who first (in para. 50) recognises a margin of discretion on the part of the Member States and then goes on (in para. 53) to claim that owing to the direct effect of purportedly horizontally effective Treaty provisions a claim against another private party may in certain instances be based directly on the relevant Treaty provision.

94. See, for that matter, Joined Cases C-6/90 and C-9/90 Francovich and Others $v$ Italian Republic [1991] ECR I-5357Case C-224/01; Gerhard Köbler v Republik Österreich [2003] ECR I-10239.

95. AG Miguel Maduro's Opinion in Case C-438/05, The International Transport Workers' Federation \& The Finish Seamen's Union v. Viking Line ABP \& Ou Viking Line Eesti, 23 May 2007, at para. 43,48 and generally paras. $42-54$. 
[...] [T] he rules on freedom of movement apply directly to any private action that is capable of effectively restricting others from exercising their right to freedom of movement.

Begriffsjurisprudenz was notorious for reasoning deductively from premises that were arrived at on the basis of bold inductions. ${ }^{96}$ Maduro revives this practice. For example, he introduces a condition of effectiveness in order to limit the horizontal scope of application of free movement rules by likening the impact of private acts to the efficacy of state regulation. He concludes that if one strange shopkeeper in England refuses to sell Irish products he does not interfere with the free movement of (Irish) goods; he would, however, if on the basis of a shared aversion to everything Irish all other shopkeepers were to do the same (see ibid., para. 42). The construction is strange. Why should the illegality of an interference with rights by one person depend on the existence of a number of the same interferences by others, which would also only amount to an interference if that one additional person acted as all others did? For example, why should the existence of one hundred clever business people whose combined acts cause the ruin of a person that lacks a "wealth talent" make the act of the last person, and with that the acts of all others, into an interference with the impoverished person's right to subsistenceassuming, for the sake of the argument, that a constitution incorporates such a right? It does not make any sense to approach the matter from that perspective. The only difference that the aggregate effect of the exercise of rights makes is that it gives the state a better reason to intervene in order to protect the rights of others, such as a hypothetical right to subsistence. Aggregate effects matter from the perspective of public policy, but not from the perspective of an individual right holder.

${ }^{96}$ See Eugen Ehrlich, Die juristische Logik (2d ed., Tübingen: Mohr, 1925). 
Arguably, what Maduro should have said is that as soon as the combined effect of a number of private acts creates an obstacle that a trader cannot reasonably be expected to overcome (see ibid., para. 48), the state is under an obligation to do something about it. Hence, contrary to Maduro, it is not by "implication" that the rules of freedom of movement apply directly to private persons as though they become capable of interfering jointly when marching along with the crowd. The only implication might be that at a certain unspecified point the state is under an obligation to do something about, say, the collective refusal on the part of English shopkeepers to sell Irish goods out of spite for Irish industry and craftsmanship. According to Maduro, the state obligation consists of giving free movement horizontal effect. This is the gist of the argument. It is, however, inconclusive, for it is open to debate whether direct horizontal effect, that is, an obligation to sell Irish products, is also the least restrictive means vis-à-vis the private autonomy of shopkeepers who are to decide for themselves which variety of products they would like to offer to customers. If that freedom were completely cancelled, free movement would indeed become tyrannical.

It does not require any further elaboration that the cancellation of the public private distinction, even though deeply problematic, is perfectly consistent with cosmopolitan reason. With the disappearance of public acts, private acts inherit their significance. 


\section{The eschatological bias}

Once the cosmopolitan mindset is submitted only to moderate scrutiny it turns out to be quite perplexing why there is so little readiness to engage with it critically. Obviously, whoever contemplates objections is afraid of revealing to himself or others attitudes that are likely to be discounted as old-fashioned, parochial, nationalistic, xenophobic, and ignorant of the blessings of global commercial society. I sense, however, that more is at stake than mere fear of public shaming or reluctance "to come out" when the spectre of critical reflection triggers uneasiness and embarrassment.

In his otherwise doubtfully imperialistic pamphlet Land und Meer, ${ }^{97}$ Carl Schmitt made two observations, which, despite the time and circumstances of their origin, are nonetheless worth pondering.

The first observation is that every ordering of human affairs also materialises in an ordering of space. Consequently, revolutions of human societies always also involve alteration of our conceptions of space. ${ }^{98}$ For Schmitt, the rise of the British Empire exemplified such a change. The new empire's element was the sea. Seen from the sea, the territory of political rule is perceived through the lens of the distinction between coast and hinterland. What matters, from the maritime perspective, is, of course, the coast. Schmitt could have added that the coast is essentially a place of embarkation and disembarkation. The de-territorialised world of the maritime empire constitutes a space that is fit for the world of commerce. The visibility of this world is structured in a manner that brings busy ports and quick exchanges into view. The metropolis

\footnotetext{
97 See Carl Schmitt, Land und Meer: Eine weltgeschichtliche Betrachtung (new edition, KölnLövenich: Hohenheim Verlag, 1981). Published in 1942, the book ends with Schmitt singing his praise of the German Luftwaffe.

${ }^{98}$ See ibid. at 64,71 .
} 
matters, the hinterland remains obscure. Whatever exists in this new space exists for the sake of transactions. ${ }^{99}$

Schmitt's other observation concerns the eschatological dimension of world history. He mentions in passing that the whole notion of world history would not appeal to us if it were not intrinsically linked to salvation (Rettung). ${ }^{100}$ As is well known, Karl Löwith would make similar, however more sceptical, observations. ${ }^{101}$ What Schmitt makes us realise, however, is that alterations of the order of space also engage our eschatological imagination. It affects, in other words, the spatial dimension along which we imagine better worlds to arise in the future.

Both observations in juxtaposition are heuristically useful. Since the eclipse of alternatives to capitalism, we have increasingly come to rest our eschatological hopes on the creation of transnational spaces. Cosmopolitanism is a vehicle of post-utopian hopes. Instead of engaging our fantasy with regard to what life might be like within a bounded unit, it reduces our political vision to living in an infinite space replete with opportunities and invigorating experiences. The vision is essentially formal and linked not to forms of human association, which are by default taken to be transient and contractual, but rather to titillating sensations triggered by mixing and from encounters with diversity and hybridity. Under the spell of this post-utopian imagination we have become disinclined to believe that humanity's future salvation from unnecessary plight might be written with national ink. We would like to believe, rather, that peace and prosperity are to be obtained in some transnational space. Within this space, parochialism and prejudice would finally have been overcome and human dealings would be

\footnotetext{
99 See ibid. at 93-97.

100 See ibid. at 83.

101 See Karl Löwith, Meaning in History: The Theological Implications of the Philosophy of History (Chicago: University of Chicago Press, 1949).
} 
sustained at the proverbial high level of health, environment, safety, and consumer protection.

Transnationalism is a political theology. It replaces a vision of salvation that is based on empowerment and collective action with a vision that perceives human greatness to arise from horizontal movements.

\section{The priority of justice}

In this sceptical vein, I return to the challenges posed by Nagel's essay. If it is true that one should not expect from a transnational context-at any rate, from one in which a great diversity of national economies participate-the type of political self-determination that triggers the obligation of justice ${ }^{102}$ then the question arises, of course, whether the participation of states can be justified against the background of their obligation to sustain just regimes. Essentially, this question concerns the priority of the right over the good. This priority means that the principles of justice take precedence over the pursuit of the economic, cultural or religious aims, either individually or collectively conceived. No matter how high the gain in welfare or cultural achievement might be, the precepts of justice have to be respected. From this follows, in particular, that even if transnational economic arrangements increase the overall size of the pie, nation states would have to withdraw from them if they engender unjustified inequalities of wealth.

The priority question is relevant, to be sure, in more than one respect.

First, the question is whether units which are already under an obligation to guarantee justice are under an obligation to abstain from participating in a

102 See Nagel, note 1 at 120. 
regime with which to comply would make it impossible to fulfil this obligation. I sense that the priority of justice would rule this categorically out.

Second, it can be asked whether in some hypothetical situation prior to society men and women ought to choose to create a unit in which justice can be realised. ${ }^{103}$ Remarkably, Nagel would reply that there is no such obligation. Just as there is no obligation to enter into a marriage and to have children, towards whom one incurs, once they have been born, special obligations, there is no obligation to submit oneself in communion with others to public power, as a consequence of which the obligations of justice would attain full force. ${ }^{104} \mathrm{I}$ do not see why that should be the case, for in comparison to the first scenario, where withdrawal is ruled out, it is difficult to understand why the choice for or against justice ought to be free as long as the creation of just institutions is feasible. Why should deciding against the possibility of just arrangements be treated differently from surrendering them to a transnational regime? The priority of justice would not make a difference here, but rather one of the specific obligations to which it gives rise, namely, the protection of legitimate expectations.

Third, on a charitable interpretation of transnational economic arrangements, the question is not whether the right is superseded by the good but rather whether it is permissible, in the course of pursuing the good, to constrain nation states in such a manner that only a certain conception of justice remains workable in practice. This means, in particular, that of all the possible conceptions only the market liberal conception would be left over. This would be justified if the establishment of transnational institutions were a precept of

\footnotetext{
103 Of course, this question raises the further question where such a hypothetical situation would hypothetically have its place: within a hypothetical nation state or a hypothetically unified globe? It is assumed here that the position "prior to society" is also a position "prior to space" and can give rise, therefore, to the question, which space ought to be chosen in order to realise justice. The assumption does not answer the objection, though, that the relevance of justice may be only a consequence of a commitment to bounded space.

104 See Nagel, note 1 at 121.
} 
justice. As we have seen already, such institutions limit the range of available social policy options. Within their context, political processes have less choice than they would have without them. Such constrains may be just in the interest of a regime's long-term stability and public tranquillity. They would also permit a modicum of social assistance. As has been pointed out above, no rational liberal society would leave its marginalised members completely to their own devices. It would use means-tested support in order to soothe the pains of the losers. ${ }^{105}$

I do not think that any theory of justice would support such a cynical conclusion. Rather, no just society would foreclose the channels of political change by subordinating political choices to the pursuit of one single conception of distributive justice. A theory of justice, in order to appeal consistently to human reason, must make itself dependent on its acceptance by a democratic citizenry. ${ }^{106}$ Otherwise, it could only be paired with some version of enlightened absolutism. A transnational regime, such as the current European Union, which is structurally biased in favour of market liberal solutions, does not fulfil this condition. For citizens for whom political change is unavailable this situation is tantamount to living under foreign rule. They may decide to accept it when they think that political self-determination is too dangerous for them since it could unsettle the pursuit of their private interests. It would be surprising, nonetheless, if a liberalism of tutelage turned out to be Europe's ultimate political philosophy.

\footnotetext{
105 For accurate observations along these lines, see Abram de Swaan, 'The receding prospects for transnational social policy' (1997) 26 Theory and Society 561-575 at 561-562.

106 See, on that topic, the famous discussion of Rawls' political liberalism by Richard Rorty, 'The priority of democracy to philosophy' In A. Malachowski (ed.), Reading Rorty (Oxford: Blackwell's, 1990) 279-302.
} 


\section{Conclusion}

The collective singular "social question" is historically associated with two different understandings. Modestly construed, the social question is about aiding the poor. Formulated with greater ambition, it concerns extricating human life as fully as possible from the relentless demands of agility and adaptability.

In a transnational context, both understandings become entangled in a complex relation of both overdetermination and conflict. It is possible to reformulate the social question only by reflecting on the broader context in which it is embedded.

Any reflection of this type will draw on either of two spatial specifications of practical reason. One is cosmopolitan, the other one political. Both have their place in a transnational context. Since the federal level typically is supported only by weak political ties, the cosmopolitan form of reflection is likely to predominate while political practical reasoning remains local.

The tension between a moderate and an ambitious rendering is thus transformed into the tension between a cosmopolitan and political account of the social question. In order to be able to tell which one is to be attributed precedence, one needs to turn to the theory of justice. It turns out, then, that the cosmopolitan perspective on social justice would not only permit greater inequalities of wealth than its political counterpart, it would also severely hamper the freedom of political beings to realise one or the other conception of justice in their communities.

Nobody, including the author, will be satisfied with the conclusion that follows from analysis. We would like not to draw it and run away from it, for we are all possessed by a transnational eschatological bias. We would like to 
see humanity's progress realised within the transnational sphere. In fact, however, we might do better when revisiting the nation state in light of fifty years of European integration. It may not be too late to pursue the federalist dream. Or it may still be possible to rescue existing national states by restraining the grip of the internal market. Both options, however, are equally superior to the status quo.

It will be objected that no movement in either direction appears to be imminent. This objection seems to be a very accurate assessment of the current state of affairs. But if neither happens, Europe will be increasingly torn apart by its unresolved social question. Lest we forget, we are not dealing with a moral precept. As Arendt was well aware of, we are confronted with a real historical force. 
The Social Question in a Transnational Context 


\section{Recent LEQS papers}

Mabbett, Deborah. 'A Rights Revolution in Europe? Regulatory and judicial approaches to nondiscrimination in insurance' LEQS Paper No. 38, May 2011

Karaman, K. Kıvanç \& Pamuk, Şevket. 'Different Paths to the Modern State in Europe: The interaction between domestic political economy and interstate competition.' LEQS Paper No. 37, May 2011

Scharpf, Fritz W.. 'Monetary Union, Fiscal Crisis and the Preemption of Democracy.' Paper presented at the LEQS Annual Lecture 'Saving the Euro - at the expense of democracy in Europe?' on 12 May 2011 at the London School of Economics, LEQS Paper No. 36, May 2011

Zigante, Valentina. 'Assessing Welfare Effects of the European Choice Agenda: The case of health care in the United Kingdom.' LEQS Paper No. 35, May 2011

Hobolth, Mogens. 'European visa cooperation: interest politics and regional imagined communities.' LEQS Paper No. 34, May 2011

Monastiriotis, Vassilis. 'Regional Growth Dynamics in Central and Eastern Europe.' LEQS Paper No. 33, April 2011

Johnston, Alison. 'The Revenge of Baumol's Cost Disease?: Monetary Union and the Rise of Public Sector Wage Inflation.' LEQS Paper No. 32, March 2011

Glendinning, Simon. “Europe, for example.' LEQS Paper No. 31, March 2011

Winkler, Heinrich August. 'Greatness and Limits of the West. The History of an Unfinished Project.' LEQS Paper No. 30, February 2011

Dani, Marco. 'Assembling the fractured European consumer.' LEQS Paper No. 29, January 2011

Joerges, Christian. 'Unity in Diversity as Europe's Vocation and Conflict's Law as Europe's Constitutional Form.' LEQS Paper No. 28, December 2010

Kylstad, Ingrid. 'Turkey and the EU: A 'new' European identity in the making?' LEQS Paper No. 27, November 2010

Costa-i-Font, Joan. 'Regional Single Currency Effects on Bilateral Trade with the European Union.' LEQS Paper No. 26, October 2010

Erkan, Ozgur. 'Spain's Referendum on the European Constitutional Treaty: A Quantitative Analysis Within the Conceptual Framework of First and Second Order Elections.' LEQS Paper No. 25, June 2010

White, Jonathan. 'Left, Right and Beyond: The Pragmatics of Political Mapping.' LEQS Paper No. 24, June 2010

Monastiriotis, Vassilis \& Zartaloudis, Sotirios. 'Beyond the crisis: EMU and labour market reform pressures in good and bad times.' LEQS Paper No. 23, June 2010

Lütz, Susanne \& Kranke, Matthias. 'The European Rescue of the Washington Consensus? EU and IMF Lending to Central and Eastern European Countries.' LEQS Paper No. 22, May 2010

Hartlapp, Miriam; Metz, Julia \& Rauh, Christian. 'The agenda set by the EU Commission: the result of balanced or biased aggregation of positions?' LEQS Paper No. 21, April 2010 
LEQS

European Institute London School of Economics Houghton Street WC2A 2AE London

Email: euroinst.LEQS@lse.ac.uk

\section{http://www2.lse.ac.uk/europeanInstitute/LEQS/Home.aspx}

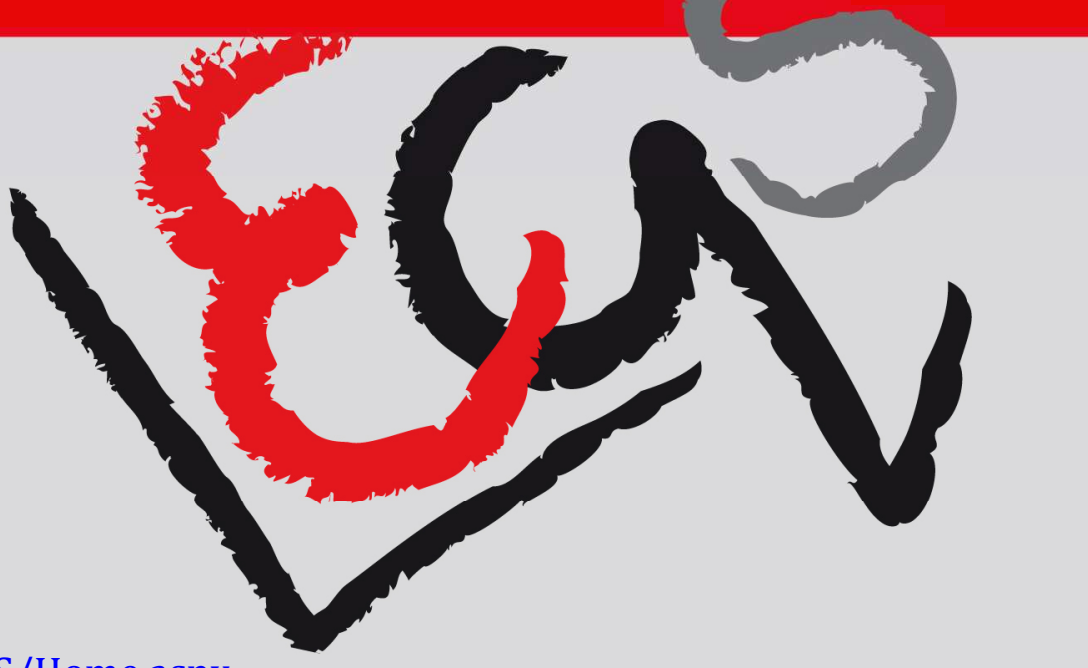

